\title{
Phylogenetic studies uncover a predominantly African lineage in a widely distributed lichen-forming fungal species
}

\author{
Paul M. Kirika,2, Pradeep K. Divakar ${ }^{3}$, Ana Crespo ${ }^{3}$, George Mugambi ${ }^{4}$,
} Elizabeth A. Orock ${ }^{5}$, Steven D. Leavitt ${ }^{6}$, Grace W. Gatheri', H. Thorsten Lumbsch ${ }^{6}$

I Department of Plant Sciences, Kenyatta University, P. O Box 43844-00100, Nairobi, Kenya 2 Botany Department, National Museums of Kenya, P.O. Box 40658-00100, Nairobi, Kenya 3 Departamento de Biología Vegetal II, Facultad de Farmacia, Universidad Complutense de Madrid, Madrid 28040 Spain 4 Department of Biological Sciences, Karatina University, P. O. Box 1957-10101, Karatina, Kenya 5 Department of Botany and Plant Physiology, University of Buea, Cameroon, P. O. Box 63, Buea, Cameroon 6 Science \& Education, The Field Museum, 1400 S. Lake Shore Drive, Chicago, IL 60605, U.S.A.

Corresponding author: H. Thorsten Lumbsch (tlumbsch@fieldmuseum.org)

Academic editor: G. Rambold | Received 20 April 2016 | Accepted 4 June 2016 | Published 15 June 2016

Citation: Kirika PM, Divakar PK, Crespo A, Mugambi G, Orock EA, Leavitt SD, Gatheri GW, Lumbsch HT (2016) Phylogenetic studies uncover a predominantly African lineage in a widely distributed lichen-forming fungal species. MycoKeys 14: 1-16. doi: 10.3897/mycokeys.14.8971

\begin{abstract}
A number of lichen-forming fungal species are widely distributed. Here, we investigate biogeographic patterns in a widely distributed isidiate taxon - Parmelinella wallichiana - using molecular sequence data. Our results revealed that Parmelinella wallichina, as currently circumscribed, is not monophyletic but falls into four clades, two of them represented by a sample only. A third clade, occurring in Africa and southern India is described as a new species, Parmelinella schimperiana Kirika \& Divakar, sp. nov. Our study adds a further example of previously overlooked, geographically distinct, lineages that were discovered using molecular data.
\end{abstract}

\section{Key words}

Africa, genealogical criteria, molecular systematics, new species, Parmeliaceae, Parmelinella, parmelioid lichens, phylogeny, taxonomy

Copyright Paul M. Kirika et al. This is an open access article distributed under the terms of the Creative Commons Attribution License (CC BY 4.0), which permits unrestricted use, distribution, and reproduction in any medium, provided the original author and source are credited. 


\section{Introduction}

The advent of DNA sequence technologies and advances in molecular phylogenetic methods have revolutionized our understanding on species delimitation and systematics in lichens and fungi in general (reviewed in Crespo and Lumbsch 2010; Lumbsch and Leavitt 2011; Divakar and Crespo 2015; Leavitt et al. 2015a). Molecular sequence data have led to the circumscription of previously overlooked species-level lineages and a number of taxonomic re-evaluations of widely distributed species in lichenized fungi. Diverse examples of widely distributed nominal taxa masking multiple, species-level diversity include: Cladia aggregata (Parnmen et al. 2012), Melanelixia glabra (Divakar et al. 2010a), Melanelixia fuliginosal M. glabratula (Leavitt et al. 2012), Melanohalea elegantula, M. exasperata (Leavitt et al. 2013a), Montanelia tominii (Leavitt et al. 2015b), Parmelia saxatilis (Molina et al. 2011a), P. sulcata (Divakar et al. 2005, Molina et al. 2011b), Parmelina quercina (Argüello et al. 2007), P. tiliacea (Nuñez-Zapata et al. 2011), Protoparmelia badia (Singh et al. 2015), Physconia distorta (Divakar et al. 2007), Rhizoplaca melanophthalma (Leavitt et al. 2013b), and Sphaerophorus globosus (Högnabba and Wedin 2003). These studies demonstrate that some supposedly cosmopolitan taxa may include previously unrecognized diversity. Thus re-evaluation of widely distributed species applying molecular sequence data is prerequisite to understanding biogeographic patterns in broadly distributed taxa. Furthermore, inaccurate species assessment may have negative consequences for conservation purposes or understanding of diversification patterns.

Parmelinella is a small genus (ca. 10 species) and belongs to the parmelioid clade in the family Parmeliaceae (Divakar et al. 2015). The species included in this genus are characterized by a pored epicortex, isolichenan in the cell walls, subirregular lobes, cylindrical or bifusiform conidia, simple cilia and rhizines, and a yellow-grey upper cortex - containing secalonic acid derivatives and atranorin (Elix 1993; Crespo et al. 2010; Thell et al. 2012). Species in the genus are mainly distributed in subtropical to tropical regions of Africa, Asia, Australasia and South America. Parmelinella chozoubae, P. manipurensis and P. nimandairana are restricted to Asia; P. salacinifera, is reported from Southeast USA, central and south America, and Thailand; P. simplicior occurs in Asia and East Africa; and P. cinerascens, $P$. lindmanii, $P$. mutata and $P$. versiformis are endemic to South America (Elisaro et al. 2010; Benatti 2014). For a long time only four additional Parmelinella species were known from India (Divakar and Upreti 2005), but recent studies added six species to the genus, most of which had previously been known to occur only in South America (Elisaro et al. 2010; Benatti 2014). Of the ten species, only two, P. simplicior and $P$. wallichiana, have previously been reported from East Africa (Swinscow and Krog 1988; Alstrup et al. 2010).

Parmelinella wallichiana is the only widely distributed species in this genus and is known from Africa, Asia, Australia and South America. While it is widespread in East Africa and Asia, the species is known from a few localities in Australia and South America. Parmelinella wallichiana normally reproduces asexually by isidia and grows in wide range of ecological environments. The species is most frequently epiphytic but 
also found rarely on rocks. Studies have demonstrated broad, intercontinental distributions of a number of lichen-forming fungi that reproduce via asexual propagules (see e.g. Divakar et al. 2005; Molina et al. 2011a and b; Leavitt et al. 2013a; Roca-Valiente et al. 2013; Divakar et al. 2016).

This study aims to assess biogeographic patterns in the widely distributed, isidiate, lichen-forming fungal species Parmelinella wallichiana. To this end, we generated DNA sequences of nuclear ribosomal internal transcribed spacer region (ITS1, 5.8S and ITS2), large subunit (nuLSU) and mitochondrial small subunit (mtSSU). Phenotypical features were re-evaluated and compared in light of the relationships inferred from the phylogenetic reconstructions.

\section{Materials and methods}

\section{Taxon sampling}

A DNA data matrix was assembled using sequences of nuclear ITS, nuLSU and mitochondrial SSU rDNA of 21 samples, representing 18 specimens of $P$. wallichiana s. lat. from Africa, Asia and S. America assembled together with DNA sequences of P. aff. wallichiana and P. lindmanii (Elisaro et al. 2010) downloaded from GenBank. GenBank accession numbers and information of studied materials are shown in Table 1. The data sets include 12 sequences from previous publications (Blanco et al. 2004; Divakar et al. 2004; Divakar et al. 2006; Divakar et al. 2010b: Eliasaro et al. 2010: Kirika et al. 2015), and 25 were newly generated for this study. Three specimens of Bulbothrix isidiza were used as an out-group since it has been shown to belong to a sister group in a previous study (Kirika et. al.2015).

\section{DNA extraction and PCR amplification}

Total genomic DNA was extracted from small pieces of thallus devoid of any visible damage or contamination using the USB PrepEase Genomic DNA Isolation Kit (USB, Cleveland, $\mathrm{OH}$ ) in accordance with the manufacturer's instructions. We generated sequence data from nuclear ribosomal markers, the ITS region and a fragment of the nuLSU, in addition to a fragment of the mtSSU. Polymerase-chain-reaction (PCR) amplifications were performed using Ready-To-Go PCR Beads (GE Healthcare, Pittsburgh, PA, USA) using the dilutions of total DNA. Fungal ITS rDNA was amplified using ITS1F primers (Gardes and Bruns 1993), ITS4 and ITS4A (White et al. 1990; Larena et al. 1999); mtSSU rDNA was amplified using the primers mrSSU1, mrSSU3R and mrSSU2R (Zoller et al. 1999); nuLSU rDNA was amplified using LR0R and LR5 (Vilgalys and Hester 1990). PCR products were visualized on 1\% agarose gel and cleaned using ExoSAP-IT (USB, Cleveland, OH, USA). Cycle sequencing of complementary strands was performed using BigDye v3.1 (Applied Biosystems, 


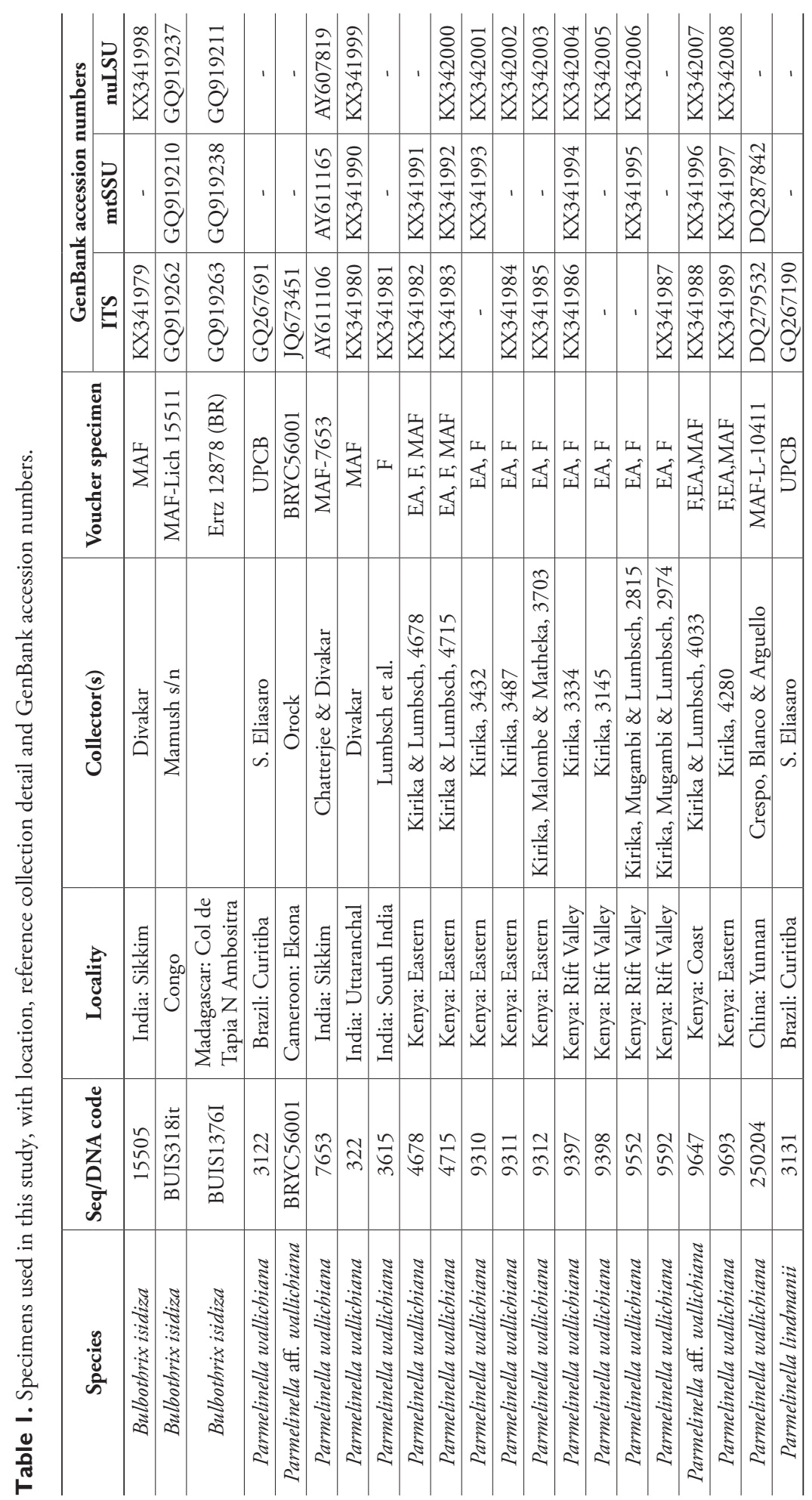


Foster City, CA, USA) and the same primers used for PCR amplifications. Sequenced PCR products were run on an ABI 3730 automated sequencer (Applied Biosystems) at the Pritzker Laboratory for Molecular Systematics and Evolution at the Field Museum, Chicago, IL, USA.

\section{Sequence editing and alignment}

New sequences were assembled and edited using GENEIOUS v8.1.7 (Biomatters Ltd. 2005-2015). Multiple sequence alignments for each locus were performed using the program MAFFT v7 (Katoh et al. 2005; Katoh and Toh 2008). For the ITS and nuLSU sequences, we used the G-INS-i alignment algorithm and '20PAM / $\mathrm{K}=2$ ' scoring matrix, with an offset value of 0.3 , and the remaining parameters were set to default values. We used the E-INS-i alignment algorithm and '20PAM / $\mathrm{K}=2$ ' scoring matrix, with the remaining parameters were set to default values for the mtSSU sequences. The program Gblocks v0.91b (Talavera and Castresana 2007) was used to delimit and remove ambiguous alignment nucleotide positions from the final alignments using the online web server (http://molevol.cmima.csic.es/castresana/Gblocks_server. html), implementing the options for a less stringent selection of ambiguous nucleotide positions, including the 'Allow smaller final blocks', 'Allow gap positions within the final blocks', and 'Allow less strict flanking positions' options.

\section{Phylogenetic analyses}

Phylogenetic relationships were inferred using maximum likelihood (ML), and Bayesian inference (BI). Exploratory phylogenetic analyses of individual gene topologies showed no evidence of well-supported ( $\geq 70 \%$ bootstrap values) topological conflict, thus relationships were estimated from a concatenated, three-locus (ITS, nuLSU, $\mathrm{mtSSU}$ ) data matrix using a total-evidence approach (Wiens 1998). We used the program RAxML v8.1.11 (Stamatakis 2006; Stamatakis et al. 2008) to reconstruct the concatenated ML gene-tree using the CIPRES Science Gateway server (http://www. phylo.org/portal2/). We implemented the 'GTRGAMMA' model, with locus-specific model partitions treating all loci as separate partitions, and evaluated nodal support using 1000 bootstrap pseudoreplicates. Exploratory analyses using alternative partitioning schemes resulted in identical topologies and highly similar bootstrap support values. We also reconstructed phylogenetic relationships from the concatenated multilocus data matrix under BI using the program BEAST v1.8.2 (Drummond and Rambaut 2007). We ran two independent Markov Chain Monte Carlo (MCMC) chains for 20 million generations, implementing a relaxed lognormal clock, a birth-death speciation process prior. The most appropriate model of DNA sequence evolution was selected for each marker using the program PartitionFinder v1.1.1 (Lanfear et al. 2012), treating the ITS1, 5.8S, ITS2, nuLSU, and $\mathrm{mtSSU}$ as separate partitions. The 
first 2 million generations were discarded as burn-in. Chain mixing and convergence were evaluated in Tracer v1.5 (Rambaut and Drummond 2009), considering ESS values $>200$ as a good indicator. Posterior trees from the two independent runs were combined using the program LogCombiner v1.8.0 (Drummond et al. 2012), and the final maximum clade credibility (MCC) tree was estimated from the combined posterior distribution of trees.

\section{Morphological and chemical studies}

Morphological characters, including lobe shape, size and width, cilia and rhizines were studied using a Leica Wild M 8 dissecting microscope. All the specimens of $P$. wallichiana included in the molecular analysis were evaluated (see Table 1). In the case of the new species, additional herbarium specimens were also studied.

Observations and measurements of ascospores were made in water, at $40 \times$ (objective) and $10 \times$ (eye piece) magnification with a Leica Leitz DM RB microscope. For each species at least 20 spores from different specimens were measured. Mean value (M) and standard deviation (SD) were calculated. In the description of the new species, the results of the measurements are given as (minimum value observed) $\mathrm{M} \pm \mathrm{SD}$ (maximum value observed). M, SD and $\mathrm{n}$ (number of spores measured) are expressed within parentheses. Chemical constituents were identified by thin layer chromatography using standard methods (Orange et al. 2010). Extraction of secondary metabolites for TLC analysis was done by pacing small pieces of the thallus in Eppendorf tubes and then adding a few drops of acetone in the tube. The resulting extract was then spotted on glass plates coated with Silica gel using capillary tubes. Plates were developed in Camag horizontal developing chamber (Oleico Lab Stockholm) using solvent system A (Toluene:Dioxane:acetic acid, 45:15:2), plates were then air dried, sprayed with 10\% sulphuric acid and then heated in an oven at 110 degrees Celsius to visualize the spots. Substances were identified by comparing the spots with controls (Orange et al. 2010).

\section{Results and discussion}

A total of 28 new DNA sequences of Parmelinella wallichiana were generated for this study (Table 1). These were deposited in GenBank under accession numbers KX341978-KX342008. The dataset included samples from wide geographic regions as Asia, East Africa and South America. The final alignment of the combined data set was 2174 positions in length and was comprised of 458 unambiguously aligned nucleotide position characters in ITS, 844 in the nuLSU, and 872 in the $\mathrm{mtSSU}$. As the topologies of the single locus phylogenies did not show any conflicts they were analyzed in a concatenated data matix (data not shown). The ML and BI analyses were identical in their topology and hence only the ML tree with support values of both analyses is depicted in Figure 1. 


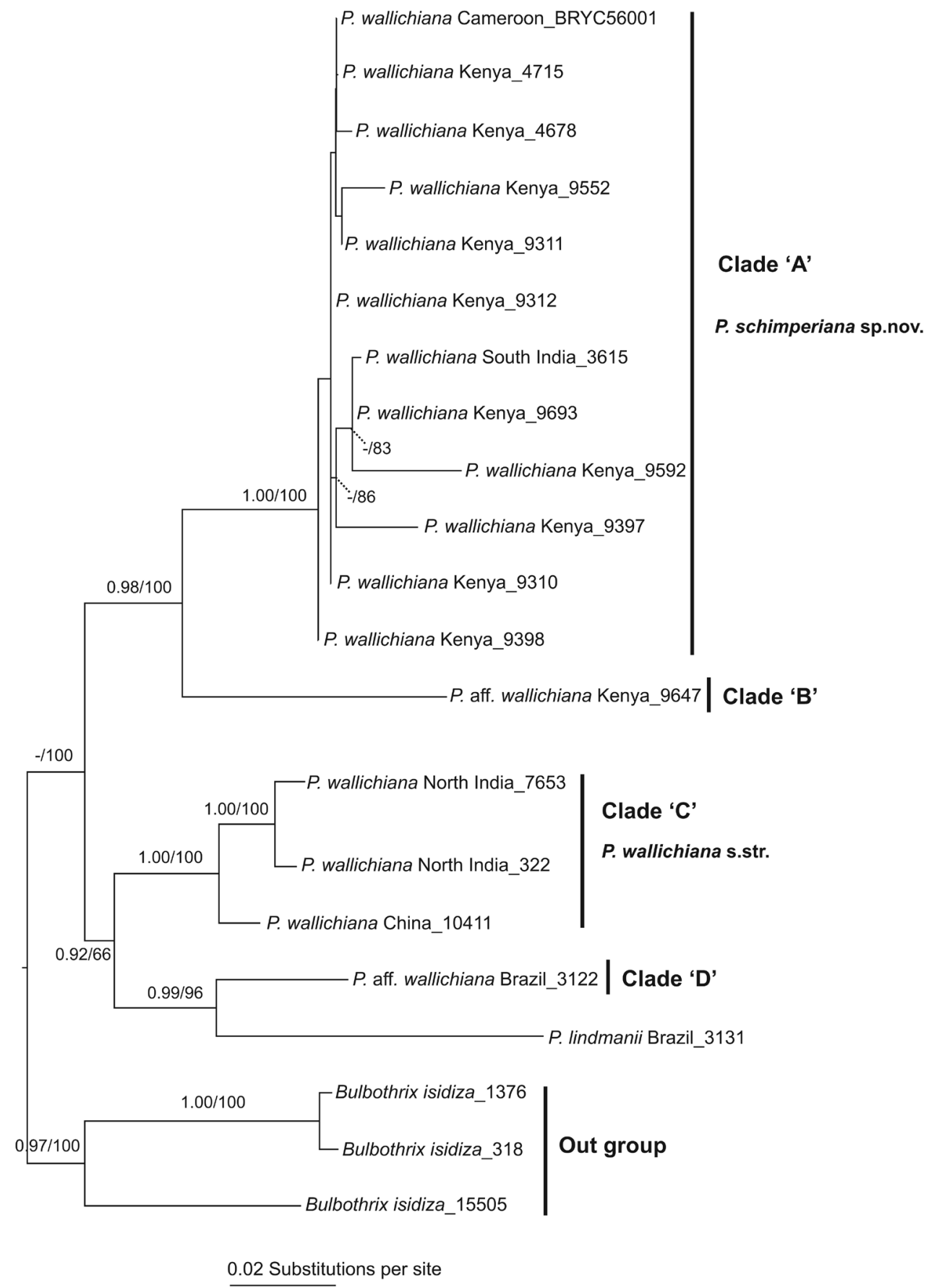

Figure I. Phylogenetic relationships among Parmelinella taxa based on a maximum-likelihood (ML) analysis of a concatenated, three locus dataset (ITS, nuLSU \& mtSSU rDNA). Since the ML and Bayesian inference topologies were identical, only the ML topology is shown here. Posterior probabilities $\geq 0.95 /$ ML bootstrap values $\geq 70 \%$ are given above the branches. 
Specimens representing Parmelinella wallichiana did not form a monophyletic lineage (Fig. 1). This is inconsistent with currently hypothesized species boundaries based on phenotypical features (Divakar and Upreti 2015; Benatti 2014). Species-level polyphylies are commonly found in Parmeliaceae and other groups of lichen-forming fungi (see reviews by Crespo and Lumbsch 2010; Lumbsch and Leavitt 2011).

Specimens representing $P$. wallichiana s. lat. fell into four distinct well-supported clades. Clade 'A' included samples from Kenya, Cameroon, and a single sample from South India. Clade 'B' included a single sample from coastal region (Coast Province) of Kenya. Clade ' $C$ ' included most samples from Asia; and clade 'D' was represented by a single sample from South America (Brazil). Specimens in clade ' $A$ ' are characterized in having smaller ascospores $(5-10 \times 5-7.5 \mu \mathrm{m})$, whereas they are larger $(15-20 \times 9-14 \mu \mathrm{m})$ in clade ' $\mathrm{C}$ '. Further, the same strongly supported monophyletic clades - 'A' and ' $C$ ' - were recovered in reciprocally monophyletic clades in the independent gene trees (data not shown) (Hudson and Coyne 2002). Presence of the same clades in different single-locus genealogies can be taken as strong evidence that the clades are reproductively and evolutionarily isolated lineages representing distinct species-level lineages (Dettman et al. 2003; Pringle et al. 2005; de Quieroz 2007). The relationships among the clades were well supported (Fig. 1). Clade 'B' formed sister-group relationship with clade 'A', whereas clade ' $\mathrm{D}$ ' was sister to $P$. lindmanii, and clade ' $\mathrm{C}$ ' sister to a clade including clade ' $\mathrm{D}$ ' and P. lindmanii. The type material of Parmelinella wallichiana is from Nepal in the Himalayas (Hale 1976a; Divakar and Upreti 2005). Since all samples sequenced by us from the Himalayan regions (China and India) clustered in clade 'C', we consider this clade as $P$. wallichiana s. str.

For clade ' $A$ ' there are a few potential names available that we studied. For example, Parmelia junodi was described from the Cape Province in South Africa (Steiner 1907) and Parmelia tiliacea var. eximia has been described from Tanzania (Steiner 1888). These taxa have previously been considered synonyms of $P$. wallichiana (Hale 1976a). However, according to a recent study by Benatti (2014), Parmelia tiliacea var. eximia is a synonym of Parmelinella cinerascens and the type material of Parmelia junodi contained mixture of different species, such as Parmelinopsis minarum or $P$. horrescens and a fragment to belonged Parmelinella cinerascens. Thus we conclude that those two names are synonyms of Parmelinella cinerascens. The latter is a rare species occurring in South America and until recently was classified in the genus Canoparmelia (Elix et al. 1986). Recently, based on morphological data, Canoparmelia cinerascens was transferred to the genus Parmelinella (see Benatti 2014). Unfortunately, we were unable to sequence this species and hence cannot confirm the phylogenetic position of $C$. cinerascens. Samples clustered in clade 'A' collected from Africa and South India are morphologically similar to Parmelinella wallichiana s. lat. Since there is no name available for this clade, a new species is described below to accommodate samples from Africa and South India (clade 'A'). Further, the segregation of this new taxon from $P$. wallichiana s.str. is corroborated by morphological data, discussed below. The new species has a disjunct distribution occurring in Africa and South India. There are 
abundant examples of this disjunct distribution pattern in flowering plants (see e.g. Mani 1974; Kadereit 2004).

Clades ' $\mathrm{B}$ ' and ' $\mathrm{D}$ ' were each represented by a single specimen from Kenya and Brazil, respectively. The sample from the coastal region of Kenya (clade 'B') has a deviating morphology, i.e. very narrow, sublinear and dichotomous lobes, although the specimen from coastal Brazil (clade 'D') was more similar to P. wallichiana s. lat. In both cases, study of additional samples will be required before a formal description of these putative species.

Our results add a further example to a growing body of evidence of the existence of distinct lineages hidden under currently circumscribed species (reviewed in Bickford et al. 2007; Crespo and Lumbsch 2010; Lumbsch and Leavitt 2011). Whereas, some studies found no obvious phenotypical differences and interpreted the discovered additional species diversity as cryptic (reviewed in Crespo and Lumbsch 2010; Lumbsch and Leavitt 2011; Hibbett 2016), re-examination of material falling into different clades uncovered previously unrecognized morphological differences. This has been shown in other cases as well (see e.g. Parmelia barrenoae, Divakar et al. (2005); Physconia thorstenii, Divakar et al. (2007); Caloplaca citrina group Vondrák et al. (2009); Melanelixia californica, Divakar et al. (2010); Parmelia mayi, Molina et al. (2011a); Cladia aggregata group, Parnmen et al. (2012); Parmotrema perforatum group, Widhelm et al. in press) and demonstrates the importance of careful re-analysis of morphological and chemical characters in order to phenotypically circumscribe species. Further, the species-level lineages uncovered in this widely distributed isidiate taxon showed biogeographic structure in what was previously believed to be a pantropical species. Although geographical structure of species detection using molecular data has recently been shown to be a common phenomenon in lichenized fungi (Argüello et al. 2007; Divakar et al. 2010a; Otalara et al. 2010; Amo de Paz et al. 2012; Parnmen et al. 2012; Moncada et al. 2014; Leaviit et al. 2015b; Alors et al. 2016); caution must be taken to generalizing for all isidate lichen taxa (Leavitt et al. 2013a; Roca-Valiente et al. 2013; Divakar et al. 2016).

\section{Taxonomic treatment}

Parmelinella schimperiana Kirika \& Divakar, sp. nov.

MycoBank No. MB 817294

Figure 2

Type. KENYA, Eastern Province, Makueni Co., Wote, Ngutwa village, Matooi hill, dry woodland, $01^{\circ} 49^{\prime} \mathrm{S}, 37^{\circ} 66^{\prime} \mathrm{E}, 1400 \mathrm{~m}$, on bark, 12 December 2013, P. Kirika, I. Malombe \& K. Matheka, 3703 (holotype: EA, isotype: F). GenBank accession number. ITS KX341985, nu LSU KX342003

Diagnosis. Morphologically similar to $P$. wallichiana but differs in having smaller ascospores $(5-10 \times 5-7.5 \mu \mathrm{m})$, being restricted in distribution to Africa and South India, and molecular phylogenetic position (Clade 'A'; Fig. 1). 


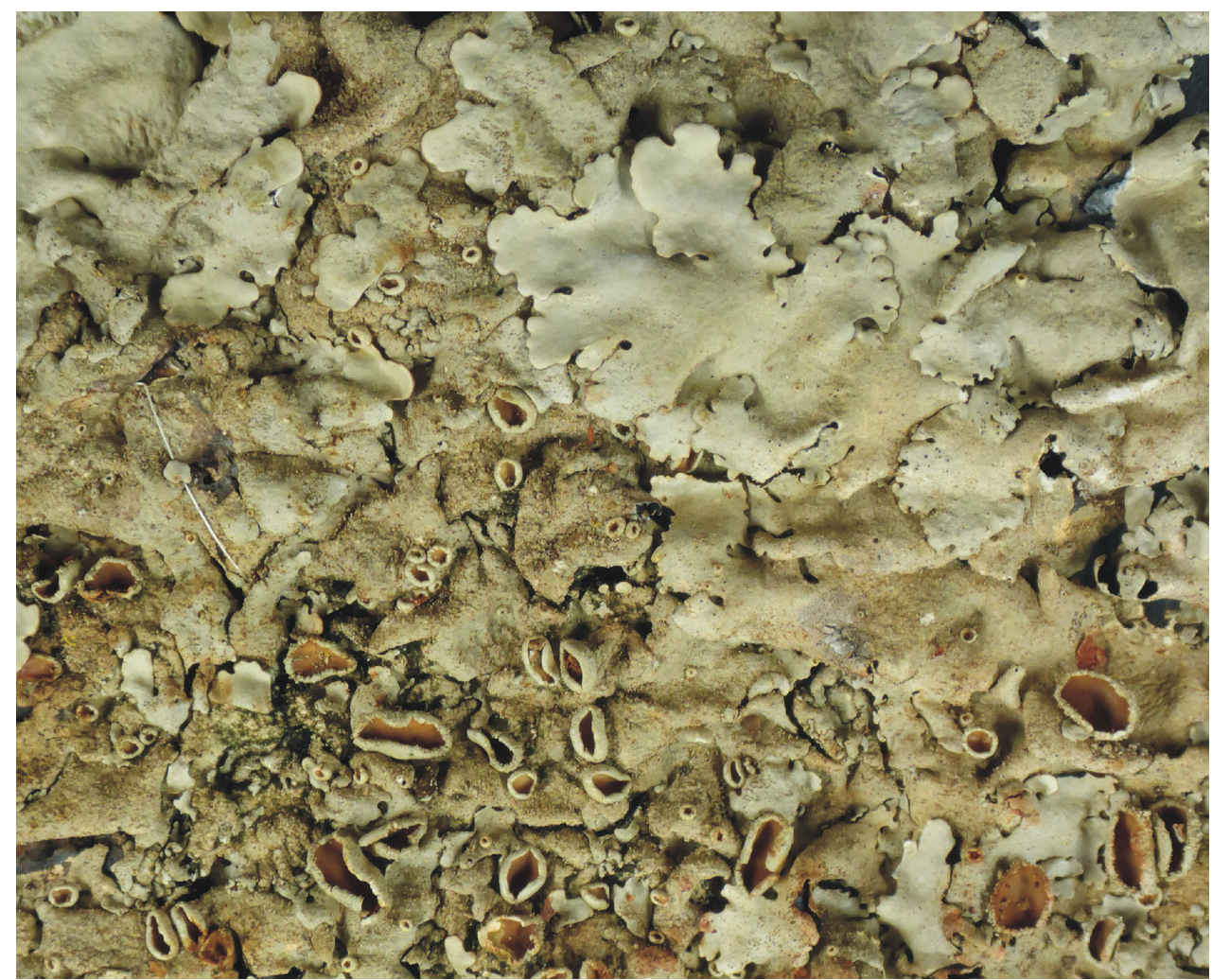

Figure 2. Morphology of the new species; Parmelinella schimperiana (holotype [EA]).

Etymology. The taxon name is in the honor of W.G. Schimper, the first botanist to collect lichens in East Africa.

Description. Thallus foliose, adnate to loosely adnate, $3-7 \mathrm{~cm}$ across. Lobes broad, irregularly to subirregularly branched, $3-8 \mathrm{~mm}$ wide, rounded crenate, with rotund apices, margins ciliate. Cilia simple, frequent in the lobe axils, $0.1-0.6 \mathrm{~mm}$ long. Upper surface grey, grey-green smooth, emaculate, usually pruinose, thallus irregularly cracked towards the centre on older parts, isidiate. Isidia laminal, cylindrical, mostly simple or branched $0.1-0.5 \mathrm{~mm}$ high, concolorous with the upper surface. Medulla white. Lower surface black with more than $2 \mathrm{~mm}$ broad, brown papillate margins, rhizinate. Rhizines black, evenly distributed, simple, $0.2-1 \mathrm{~mm}$ long. Apothecia laminal, adnate to sessile, $1-5 \mathrm{~mm}$ in diameter. Disc concave, brown, imperforate. Asci 8-spored. Ascospores ellipsoid to subglobose, 5-10 × 5-7.5 $\mu \mathrm{m}(\mathrm{M}=5.5-6.4 \times$ 7.6-8.5 $\mu \mathrm{m}, \pm \mathrm{SD}=0.7-1.0 \times 1.0-2.3 \mu \mathrm{m}, \mathrm{n}=100)$. Pycnidia absent.

Secondary chemistry - Cortex K+ yellow, UV-; medulla K+ yellow turning red, C-, $\mathrm{KC}-$, P+ orange-red, UV-; upper cortex with secalonic acid A and atranorin, medulla with salazinic acid. 
Distribution and ecology. At present the new species is known from Kenya, Cameroon and South India. It occurs in montane regions and in dry woodland areas. It is predominantly corticolous and sometimes saxicolous rarely terricolous, found corticolous on Mangifera indica, Juniperus procera, Podocarpus spp., Lannaea spp. and on Eucalyptus in artificial habitats.

Additional specimens examined. KENYA. Eastern Prov.: Marsabit Co., Marsabit National Park, Lake Paradise, disturbed forest on ridge, $2^{\circ} 16^{\prime} \mathrm{N} 37^{\circ} 56^{\prime} \mathrm{E}, 1434 \mathrm{~m}$, on bark, P. Kirika 4678 \& H.T. Lumbsch (EA, F, MAF). Eastern Prov.: Marsabit National Park at roadside between Marsabit Lodge and Lake Paradise, forest on slope, $2^{\circ} 18^{\prime} \mathrm{N} 37^{\circ} 57^{\prime} \mathrm{E}, 1513 \mathrm{~m}$, on bark, P. Kirika 4715 \& H.T. Lumbsch (EA, F, MAF). Eastern Prov.: Tharaka South, Chiakariga, Kijege Hill, Acacia-Commiphora woodland, $00^{\circ} 16$ 'S, $37^{\circ} 50^{\prime}$ E, $1160 \mathrm{~m}$, on bark, P. Kirika 3432 (EA, F). Eastern Prov.: Mwingi Co., Mumoni Hill, Eucalyptus plantation, $00^{\circ} 31^{\prime} \mathrm{S}, 38^{\circ} 00^{\prime} \mathrm{E}, 1620-1695 \mathrm{~m}$, on bark, P. Kirika 3487 \& G. Mugambi (EA, F). Eastern Prov.: Tharaka South, Chiakariga, Kijege Hill, Acacia-Commiphora-Encephalartos woodland, $00^{\circ} 16^{\prime}$ S, $37^{\circ} 50^{\prime} \mathrm{E}, 1160 \mathrm{~m}$, P. Kirika 3436 (EA, F). Rift Valley: Eldama Ravine, Lembus Forest off Eldama Ravine-Eldoret Road, remnant montane forest, $0^{\circ} 13^{\prime} \mathrm{N}, 35^{\circ} 69^{\prime} \mathrm{E}$, 2275 m, on bark, P. Kirika 2870, G. Mugambi \& H.T. Lumbsch (EA, F); $0^{\circ} 16^{\prime} \mathrm{N}$, $35^{\circ} 75^{\prime}$ E, $2137 \mathrm{~m}$, on rock, P. Kirika 2815, G. Mugambi \& H.T. Lumbsch (EA, F). Rift Valley: Kericho, James Finlay Tea Estate, Chomogondy, secondary forest, $00^{\circ} 23^{\prime} \mathrm{S}, 35^{\circ} 18^{\prime} \mathrm{E}, 2056 \mathrm{~m}$, on bark, P. Kirika 3145 (EA, F). Rift Valley: small disturbed remnant forest in tea plantation, $0^{\circ} 44^{\prime} \mathrm{S}, 35^{\circ} 31^{\prime} \mathrm{E}, 2049 \mathrm{~m}$, on bark, P. Kirika 2974 G. Mugambi \& H.T. Lumbsch (EA, F). Rift Valley: Bomet, Koiwa, Unilever riparian forest, $00^{\circ} 35 \mathrm{~S}, 35^{\circ} 17^{\prime} \mathrm{E}, 2030 \mathrm{~m}$, on bark, P.Kirika 4900 (EA). Rift Valley: Kajiado Co., Ngong Hills, Upland grassland with rocky outcrops, $01^{\circ} 24^{\prime} \mathrm{S}, 36^{\circ} 38^{\prime} \mathrm{E}$, 2430m, on soil, P. Kirika 3334 (EA, F). CAMEROON. E of Mount Cameroon, vic. of Ekona, E.A. Orock 56009 (BRY-C). INDIA. S India: Tamil Nadu, Vellore distr., Yellagiri hills, $13^{\circ} 30^{\prime} \mathrm{N}, 79^{\circ} 05^{\prime} \mathrm{E}, 1393 \mathrm{~m}$, on Mangifera indica tree trunk, hill side with teak and eucalyptus vegetation, H.T., Lumbsch, P.K. Divakar, D.K. Upreti, J. Tandon 19705a (MAF).

Remarks. Parmelinella schimperiana is morphologically most similar to P. wallichiana, but differs in having smaller ascospores $(5-10 \times 5-7.5 \mu \mathrm{m})$, whereas the ascospore size in $P$ wallichiana is: $15-20 \times 9-14 \mu \mathrm{m}$.

\section{Acknowledgments}

Newly obtained DNA sequences were generated in the Pritzker Laboratory for Molecular Systematics and Evolution at the Field Museum and at the Molecular Laboratory, Department of Biology, Faculty of Pharmacy, Complutense University of Madrid. This study was supported by a grant of the IDP/The Field Museum Africa Training Fund and the Spanish Ministerio de Ciencia e Innovación (CGL2013-42498-P). 


\section{References}

Alors D, Lumbsch HT, Divakar PK, Leavitt SD, Crespo A (2016) An integrative approach for understanding diversity in the Punctelia rudecta species complex (Parmeliaceae, Ascomycota). PLoS ONE 11(2): e0146537. doi: 10.1371/journal.pone.0146537

Alstrup V, Aptroot A, Divakar PK, LaGreca S, Tibell L (2010) Lichens from Tanzania and Kenya III. Macrolichens and calicioid lichens. Cryptogamie Mycologie 31: 333-351.

Amo de Paz G, Crespo A, Cubas P, Elix JA, Lumbsch HT (2012) Transoceanic dispersal and subsequent diversification on separate continents shaped diversity of the Xanthoparmelia pulla group (Ascomycota). PLoS ONE 7(6): e39683. doi: 10.1371/journal.pone.0039683

Argüello A, Del Prado R, Cubas P, Crespo A (2007) Parmelina quercina (Parmeliaceae, Lecanorales) includes four phylogenetically supported morphospecies. Biological Journal of the Linnean Society 91: 455-467. doi: 10.1111/j.1095-8312.2007.00810.x

Blanco O, Crespo A, Divakar PK, Esslinger TL, Hawksworth DL, Lumbsch HT (2004b) Melanelixia and Melanohalea, two new genera segregated from Melanelia (Parmeliaceae) based on molecular and morphological data. Mycological Research 108: 873-884. doi: $10.1017 /$ S0953756204000723

Benatti MN (2014) An update on the genus Parmelinella Elix \& Hale (Parmeliaceae, lichenized Ascomycetes). Mycosphere 5: 770-789.

Bickford D, Lohman DJ, Sodhi NS, Ng PKL, Meier R, Winker K, Ingram KK, Das I (2007) Cryptic species as a window on diversity and conservation. Trends in Ecology and Evolution 3: 148-155. doi: 10.1016/j.tree.2006.11.004

Biomatters Ltd. (2005-2015) GENEIOUSr8. http:/www.geneious.com/previous-versions

Crespo A, Lumbsch HT (2010) Cryptic species in lichen-forming fungi. IMA Fungus 1: 167-170. doi: 10.5598/imafungus.2010.01.02.09

Crespo A, Kauff F, Divakar PK, Amo G, Argüello A, Blanco O, Cubas P, del Prado R, Elix JA, Esslinger TL, Ferencova Z, Hawksworth DL, Lutzoni F, Millanes AM, Molina MC, PerezOrtega S, Wedin M, Ahti T, Bungartz F, Calvelo S, Aptroot A, Barreno E, Candan M, Cole M, Ertz D, Goffinet B, Lindblom L, Lücking R, Mattsson JE, Messuti MI, Miadlikowska J, Piercey-Normore M, Rico V, M. Sipman HJ, Schmitt I, Spribille T, Thell A, Thor G, Lumbsch HT (2010) Phylogenetic generic classification of parmelioid lichens (Parmeliaceae, Ascomycota) based on molecular, morphological and chemical evidence. Taxon 59: 1735-1753.

Crespo A, Lumbsch HT, Mattsson JE, Blanco O, Divakar PK, Articus K, Wiklund E, Bawingan PA, Wedin M (2007) Testing morphology-based hypotheses of phylogenetic relationships in Parmeliaceae (Ascomycota) using three ribosomal markers and the nuclear RPB1 gene. Molecular Phylogenetics and Evolution 44: 812-824. doi: 10.1016/j.ympev.2006.11.029

de Queiroz K (2007) Species concepts and species delimitation. Systematic Biology 56: 879-886. doi: 10.1080/10635150701701083

Dettman JR, Jacobson DJ, Taylor JW (2003) A multilocus genealogical approach to phylogenetic species recognition in the model eukaryote neurospora. Evolution 57: 2703-2720. doi: 10.1111/j.0014-3820.2003.tb01514.x

Divakar PK, Upreti DK (2005) Parmelioid lichens in India (A revisionary study). Bishen Singh Mahendra Pal Singh, Dehra Dun, 1-488. 
Divakar PK, Crespo A (2015) Molecular phylogenetic and phylogenomic approaches in studies of lichen systematics and evolution. In: Upreti DK, Divakar PK, Shukla V, Bajpai R (Eds) Recent Advances in Lichenology. Springer India, India, 45-60. doi: 10.1007/978-81-3222235-4_3

Divakar PK, Molina MC, Lumbsch HT, Crespo A (2005) Parmelia barrenoae, a new lichen species related to Parmelia sulcata (Parmeliaceae) based on molecular and morphological data. Lichenologist 37: 37-46. doi: 10.1017/S0024282904014641

Divakar PK, Crespo A, Blanco O, Lumbsch HT (2006) Phylogenetic significance of morphological characters in the tropical Hypotrachyna clade of parmelioid lichens (Parmeliaceae, Ascomycota). Molecular Phylogenetics and Evolution 40: 448-458. doi: 10.1016/j. ympev.2006.03.024

Divakar PK, Amo De paz G, del Prado R, Esslinger TL, Crespo A (2007) Upper cortex anatomy corroborates phylogenetic hypothesis in species of Physconia (Ascomycota, Lecanoromycetes). Mycological Research 111: 1311-1320. doi: 10.1016/j.mycres.2007.08.009

Divakar PK, Figueras G, Hladun N, Crespo A (2010a) Molecular phylogenetic studies reveal an undescribed species within the North American concept of Melanelixia glabra (Parmeliaceae). Fungal Diversity 42: 47-55. doi: 10.1007/s13225-010-0027-3

Divakar PK, Ferencova Z, Del Prado R, Lumbsch HT, Crespo A (2010b) Remototrachyna, a new tropical lineage in hypotrachynoid lichens (Parmeliaceae, Ascomycota): a multigene and morphological approach. American Journal of Botany 97: 579-590. doi: 10.3732/ ajb.0900140

Divakar PK, Crespo A, Wedin M, Leavitt SD, Hawksworth DL, Myllys L, McCune B, Randlane T, Bjerke JW, Ohmura Y, Schmitt I, Boluda CG, Alors D, Roca-Valiente B, Del-Prado R, Ruibal C, Buaruang K, Núńez-Zapata J, Amo de Paz G, Rico VJ, Molina MC, Elix JA, Esslinger TL, Tronstad IKK, Lindgren H, Ertz D, Gueidan C, Saag L, Mark K, Singh G, Dal Grande F, Parnmen S, Beck A, Benatti MN, Blanchon D, Candan M, Clerc P, Goward T, Grube M, Hodkinson BP, Hur J-S, Kantvilas G, Kirika PM, Lendemer J, Mattsson J-E, Messuti MI, Miadlikowska J, Nelsen M, Ohlson JI, Pérez-Ortega S, Saag A, Sipman HJM, Sohrabi M, Thell A, Thor G, Truong C, Yahr R, Upreti DK, Cubas P, Lumbsch HT (2015) Evolution of complex symbiotic relationships in a morphologically derived family of lichenforming fungi. New Phytologist 208: 1217-1226. doi: 10.1111/nph.13553

Divakar PK, Leavitt SD, Molina MC, Del-Prado R, Lumbsch HT, Crespo A (2016) A DNA barcoding approach for identification of hidden diversity in Parmeliaceae (Ascomycota): Parmelia sensu stricto as a case study. Botanical Journal of the Linnean Society 180: 2129. doi: $10.1111 /$ boj. 12358

Drummond A, Rambaut A (2007) BEAST: Bayesian evolutionary analysis by sampling trees. BMC Evolutionary Biology 7: 214. doi: 10.1186/1471-2148-7-214

Drummond AJ, Suchard MA, Xie D, Rambaut A (2012) Bayesian phylogenetics with BEAUti and the BEAST 1.7. Molecular Biology and Evolution 29: 1969-1973. doi: 10.1093/ $\mathrm{molbev} / \mathrm{mss} 075$

Elisaro S, Cruz LM, Iacomini M, Pedrosa OF, Cordeiro LMC (2010) Phylogenetic relationship of Parmelia lindmanii (Parmeliaceae) inferred by analysis of its nuITS rDNA sequence. Lichenologist 42: 423-428. doi: 10.1017/S0024282910000034 
Elix JA (1993) Progress in the generic delimitation of Parmelia sensu lato lichens (Ascomycotina: Parmeliaceae) and a synoptic key to the Parmeliaceae. The Bryologist 96: 359-383. doi: $10.2307 / 3243867$

Elix JA, Johnston J, Verdon D (1986) Canoparmelia, Paraparmelia and Relicinopsis, three new genera in the Parmeliaceae (lichenized Ascomycotina). Mycotaxon 27: 271-282.

Hale ME (1976a) A monograph of the lichen genus Parmelina Hale (Parmeliaceae). Smithsonian Contributions to Botany 33: 1-60. doi: 10.5479/si.0081024x.33

Hale ME (1976b) A Monograph of the Lichen Genus Pseudoparmelia Lynge (Parmeliaceae). Smithsonian Contributions to Botany 31: 1-62.

Hibbett D (2016) The invisible dimension of fungal diversity. Science 351: 1150. doi: 10.1126/ science.aae 0380

Högnabba F, Wedin M (2003) Molecular phylogeny of the Sphaerophorus globosus species complex. Cladistics 19: 224-232. doi: 10.1111/j.1096-0031.2003.tb00365.x

Hudson RR, Coyne JA (2002) Mathematical consequences of the genealogical species concept. Evolution 56: 1557-1565. doi: 10.1111/j.0014-3820.2002.tb01467.x

Kadereit JW (Ed.) (2004) Flowering Plants Dicotyledons. Springer-Verlag, Berlin, Heidelberg. doi: 10.1007/978-3-642-18617-2

Katoh K, Kuma K-I, Toh H, Miyata T (2005) MAFFT version 5: improvement in accuracy of multiple sequence alignment. Nucleic Acids Research 33: 511-518. doi: 10.1093/nar/gki198

Katoh K, Toh H (2008) Recent developments in the MAFFT multiple sequence alignment program. Briefings in Bioinformatics 9: 286-298. doi: 10.1093/bib/bbn013

Kirika PM, Leavitt SD, Divakar PK, Crespo A, Gatheri GW, Mugambi G, Lumbsch HT (2015) The monotypic genus Bulborrhizina belongs to Bulbothrix sensu lato (Parmeliaceae, Ascomycota). Bryologist 118: 164-169. doi: 10.1639/0007-2745-118.2.164

Lanfear R, Calcott B, Ho SY, Guindon S (2012) PartitionFinder: combined selection of partitioning schemes and substitution models for phylogenetic analyses. Molecular Biology and Evolution 29: 1695-1701. doi: 10.1093/molbev/mss020

Larena I, Salazar O, González V, Julián MC, Rubio V (1999) Design of a primer for ribosomal DNA internal transcribed spacer with enhanced specificity for Ascomycetes. Journal of Biotechnology 75: 187-194. doi: 10.1016/S0168-1656(99)00154-6

Leavitt SD, Esslinger TL, Divakar PK, Lumbsch HT (2012) Miocene divergence, phenotypically cryptic lineages, and contrasting distribution patterns in common lichen-forming fungi (Ascomycota: Parmeliaceae). Biological Journal of the Linnean Society 1007: 920-937. doi: 10.1111/j.1095-8312.2012.01978.x

Leavitt SD, Esslinger TL, Spribille T, Divakar PK, Lumbsch HT (2013a) Multilocus phylogeny of the lichen-forming fungal genus Melanohalea (Parmeliaceae, Ascomycota): Insights on diversity, distributions, and a comparison of species tree and concatenated topologies. Molecular Phylogenetics and Evolution 66: 138-152. doi: 10.1016/j.ympev.2012.09.013 Leavitt SD, Fernández-Mendoza F, Pérez-Ortega S, Sohrabi M, Divakar PK, Lumbsch HT, St. Clair LL (2013b) DNA barcode identification of lichen-forming fungal species in the Rhizoplaca melanophthalma species-complex (Lecanorales, Lecanoraceae), including five new species. MycoKeys 7: 1-22. doi: 10.3897/mycokeys.7.4508 
Leavitt SD, Moreau CS, Lumbsch HT (2015a) The Dynamic Discipline of Species Delimitation: Progress Toward Effectively Recognizing Species Boundaries in Natural Populations. In: Upreti DK, Divakar PK, Shukla V, Bajpai R (Eds) Recent Advances in Lichenology. Springer India, 11-44.

Leavitt SD, Divakar PK, Ohmura Y, Wang L-S, Esslinger TL, Lumbsch HT (2015b) Who's getting around? Assessing species diversity and phylogeography in the widely distributed lichen-forming fungal genus Montanelia (Parmeliaceae, Ascomycota). Molecular Phylogenetics and Evolution 90: 85-96. doi: 10.1016/j.ympev.2015.04.029

Lumbsch HT, Leavitt SD (2011) Goodbye morphology? A paradigm shift in the delimitation of species in lichenized fungi. Fungal Diversity 50: 59-72. doi: 10.1007/s13225-011-0123-z

Mani MS (Ed.) (1974) Ecology and Biogeography in India. Springer Netherlands. doi: 10.1007/978-94-010-2331-3

Molina MC, Del-Prado R, Divakar P, Sánchez-Mata D, Crespo A (2011a) Another example of cryptic diversity in lichen-forming fungi: the new species Parmelia mayi (Ascomycota: Parmeliaceae). Organisms Diversity \& Evolution 11: 331-342. doi: 10.1007/s13127011-0060-4

Molina MC, Divakar PK, Millanes AM, Sanchez E, Del-Prado R, Hawksworth DL, Crespo A (2011b) Parmelia sulcata (Ascomycota: Parmeliaceae), asympatric monophyletic species complex. Lichenologist 43: 585-601. doi: 10.1017/S0024282911000521

Moncada B, Reidy B, Lücking R (2014) A phylogenetic revision of Hawaiian Pseudocyphellaria (lichenized Ascomycota: Lobariaceae) reveals eight new species and a high degree of inferred endemism. Bryologist 117: 119-160. doi: 10.1639/0007-2745-117.2.119

Nunez-Zapata J, Divakar PK, Del Prado R, Cubas P, Hawksworth DL, Crespo A (2011) Conundrums in species concepts: the discovery of a new cryptic species segregated from Parmelina tiliacea (Parmeliaceae, Ascomycota). Lichenologist 43: 603-616. doi: 10.1017/ S002428291100051X

Otálora MAG, Martínez I, Aragón G, Molina MC (2010) Phylogeography and divergence date estimates of a lichen species complex with a disjunct distribution pattern. American Journal of Botany 97: 216-223. doi: 10.3732/ajb.0900064

Orange A, James PW, White FJ (2010) Microchemical Methods for the Identification of Lichens. British Lichen Society, London, 101 pp.

Parnmen S, Rangsiruji A, Mongkolsuk P, Boonpragob K, Nutakki A, Lumbsch HT (2012) Using phylogenetic and coalescent methods to understand the species diversity in the Cladia aggregata complex (Ascomycota, Lecanorales). PLoS ONE 7(12): e52245. doi: 10.1371/ journal.pone.0052245

Pringle A, Baker DM, Platt JL, Wares JP, Latge JP, Taylor JW (2005) Cryptic speciation in the cosmopolitan and clonal human pathogenic fungus Aspergillus fumigatus. Evolution 59: 1886-1899. doi: 10.1111/j.0014-3820.2005.tb01059.x

Rambaut A, Drummond AJ (2009) Tracer version 1.5. http://tree.bio.ed.ac.uk/software/tracer/ Roca-Valiente B, Divakar PK, Ohmura Y, Hawksworth DL, Crespo A (2013) Molecular phylogeny supports the recognition of the two morphospecies Parmotrema pseudotinctorum and Parmotrema tinctorum as two distinct species. Vieraea 41: 333-348. 
Singh G, Dal Grande F, Divakar PK, Otte J, Leavitt SD, Szczepanska K et al. (2015) Coalescent-Based Species Delimitation Approach Uncovers High Cryptic Diversity in the Cosmopolitan Lichen-Forming Fungal Genus Protoparmelia (Lecanorales, Ascomycota). PLoS ONE 10(5): e0124625. doi: 10.1371/journal.pone.0124625

Stamatakis A (2006) RAxML-VI-HPC: maximum likelihood-based phylogenetic analyses with thousands of taxa and mixed models. Bioinformatics 22: 2688-2690. doi: 10.1093/bioinformatics/btl446

Stamatakis A, Hoover P, Rougemont J (2008) A Rapid Bootstrap Algorithm for the RAxML Web Servers. Systematic Biology 57: 758-771. doi: 10.1080/10635150802429642

Steiner J (1888) Ueber afrikanische Flechten. Jahresbericht der Schleischen Gesellschaft für vaterländische Cultur 66: 133-150.

Steiner J (1907) Lichenes austro-africani. Bulletin de l'Herbier Boissier 2 sér., 7: 637-646.

Swinscow TDV, Krog H (1988) Macrolichens of East Africa. British Museum (Natural History), London, 390 pp.

Talavera G, Castresana J (2007) Improvement of phylogenies after removing divergent and ambiguously aligned blocks from protein sequence alignments. Systematic Biology 56: 564-577. doi: 10.1080/10635150701472164

Thell A, Crespo A, Divakar PK, Kärnefelt I, Leavitt SD, Lumbsch HT, Seaward MRD (2012) A review of the lichen family Parmeliaceae - history, phylogeny and current taxonomy. Nordic Journal of Botany 30: 641-664.

Vondrák J, Ríha P, Arup U, Søchting U (2009) The taxonomy of the Caloplaca citrina group (Teloschistaceae) in the Black Sea region: with contributions to the cryptic species concept in lichenology. Lichenologist 41: 571-604. doi: 10.1017/S0024282909008317

Vilgalys R, Hester M (1990) Rapid genetic identification and mapping of enzymatically amplified ribosomal DNA from several Cryptococcus species. Journal of Bacteriology 172: 4238-4246.

Wiens JJ (1998) Combining data sets with different phylogenetic histories. Systematic Biology 47: 568-581. doi: 10.1080/106351598260581

White TJ, Bruns TD, Lee S, Taylor J (Eds) (1990) Amplification and direct sequencing of fungal ribosomal RNA genes for phylogenetics. Academic Press, San Diego, CA. doi: 10.1016/b978-0-12-372180-8.50042-1

Zoller S, Scheidegger C, Sperisen C (1999) PCR primers for the amplification of mitochondrial small subunit ribosomal DNA of lichen-forming ascomycetes. Lichenologist 31: 511-516. doi: $10.1017 /$ S0024282999000663 